University for Business and Technology in Kosovo

UBT Knowledge Center

Fall 9-2019

\title{
Vlerat nutricionale (ushqyese) të dredhzës dhe ndikimi në shëndetin e njeriut
}

\section{Sara Selimi}

University for Business and Technology - UBT

Follow this and additional works at: https://knowledgecenter.ubt-uni.net/etd

Part of the Food Science Commons

\section{Recommended Citation}

Selimi, Sara, "Vlerat nutricionale (ushqyese) të dredhzës dhe ndikimi në shëndetin e njeriut" (2019).

Theses and Dissertations. 7.

https://knowledgecenter.ubt-uni.net/etd/7

This Thesis is brought to you for free and open access by the Student Work at UBT Knowledge Center. It has been accepted for inclusion in Theses and Dissertations by an authorized administrator of UBT Knowledge Center. For more information, please contact knowledge.center@ubt-uni.net. 


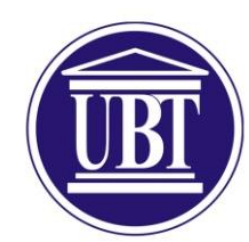

Kolegji UBT

Fakulteti: Shkencat e Ushqimit dhe Bioteknologji

Specializimi: Nutricion

\section{VLERAT NUTRICIONALE ( USHQYESE) TË DREDHZËS DHE NDIKIMI NË SHËNDETIN E NJERIUT \\ Shkalla Bachelor}

Sara Selimi

Shtator / 2019

Prishtinë 


\title{
UBI
}

Kolegji UBT

Fakulteti:Shkencat e Ushqimit dhe Bioteknologji

Specializimi: Nutricion

Punim Diplome

Viti akademik 2016-2017

Sara Selimi

\section{VLERAT NUTRICIONALE ( USHQYESE) TË DREDHZËS DHE NDIKIMI NË SHËNDETIN E NJERIUT}

\author{
Mentori: Dr.sc.Hyrie Koraqi
}

Shtator / 2019

Ky punim është përpiluar dhe dorëzuar në përmbushjen e kërkesave të pjesshme për Shkallën Bachelor 


\section{ABSTRAKT}

Dredhëzat (Fragaria x Ananassa Duch.) si fruta vlerësohen të jenë të rëndësishme në dietën tonë për shkak të karakteristikave të tyre senzorike dhe vlerave ushqyese. Dredhëzat janë shumë të dobishme për aktivitetin biologjik në shëndetin e njeriut. Qëllimi i këtij studimi ishte analizimi e cilësisë ushqyese duke u bazuar në parametrat kimik të mostrave të dredhëzave të freskëta të marra nga plantacionionet në Kosovë pas fazës së pjekjes.Parametrat e mëposhtëm të cilësisë të cilat u përcaktuan në frutin e dredhëzës janë: $\mathrm{pH}$, materia e thatë, materiet e ngurta të tretshme (TSS) e shpehur në shkallën ${ }^{\circ}$ Brix, aciditeti total (TA), raporti TSS/TA,Vitamina $\mathrm{C}$, sheqerënat totale,sheqerënat e reduktuara, proteinat dhe lipidet.Rezultatet tona mund të përdoren për të informuar kultivuesit e dredhëzave si dhe konsumatorët për cilësitë ushqyese të tyre. Përbërja e pasur ushqyese e frutave të studiuar i bën ato fruta shumë të vecantë. Një konsum i lartë i ushqimeve bimore, siç janë dredhëzat,ul rrezikun e mbipeshes, diabetit, semundjeve të zemrës dhe vdekshmerinë.Ky studim duke u bazuar në rezultatet e këtij fruti mjaft të konsumuar dhe kultivuar në Kosovë kontribuon në mënyrën e shëndetshme të jetesës, uljen e riskut për sëmundje të ndryshme dhe mirëqenie të përgjithshme.Të gjitha analizat statistikore janë punuar duke përdorur programi MS Excel dhe programi statistikor SPSS 22.0. 


\section{MIRËNJOHJE/FALENDERIME}

Pjesa eksperimentale e kësaj teme është përfunduar në kampusin e UBT-së në Lipjan, në laboratoret për analiza kimike dhe analitike. Me shumë kënaqësi shpreh mirënjohjen për stafin e departamentit tonë qё na mundësuan të pëfundojmë analizat e parapara. Falenderim $i$ veçantë i takon mentores time Dr.sc.Hyrie Koraqit, qü me njohjet e saja dhe durimin ishte përkrahja ime më e madhe duke më motivuar, udhëhequr dhe plotësuar me informacionet $e$ nevojshme që kanë plotësuar punimin tim.Falenderim tjetër i takon koleges time, Diellza Azemi që gjatë punës eksperimentale ishte përkrahja ime me ndihmën, mirësinë dhe mbështetjen e saj në finalizimin e rezultateve gjatë fazës eksperimentale.

Asnjëherë nuk do të jetë e mjaftueshme të shpreh falenderimin dhe mirënjohjen ndaj familjes sime që kanë qenë përkrahja ime më e madhe nga fillimi i studimeve dhe gjatë rrugëimit tim. Rrugëtimi im akademik nuk do të ishte i mundur pa mbështetjen e tyre! 


\section{PËRMBAJTJA}

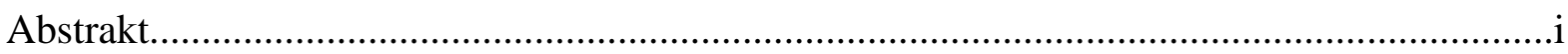

1.Hyrje

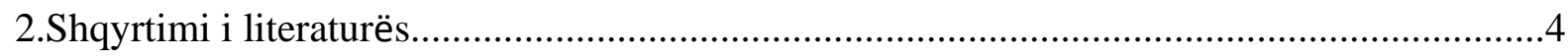

2.1.Vlerat ushqyese të dredhëzës......................................................................................

2.2.Komponentët ushqyes të dredhëzës dhe ndikimi në organizmin e njeriut...........................5

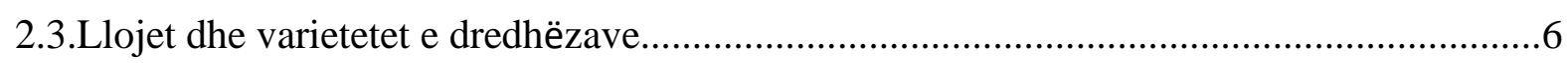

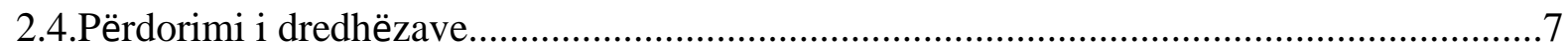

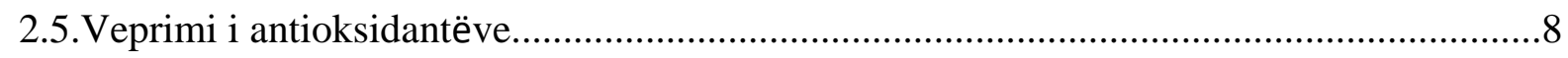

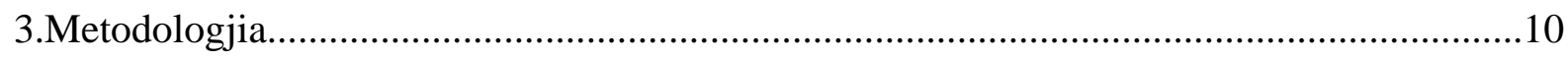

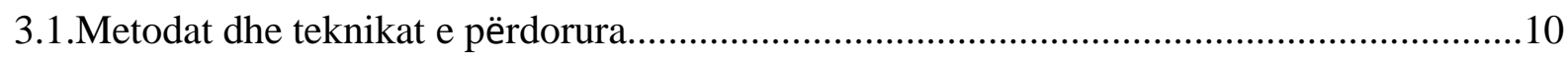

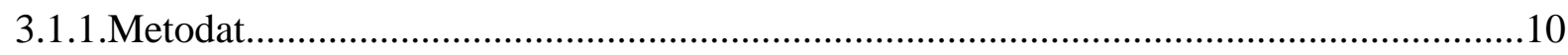

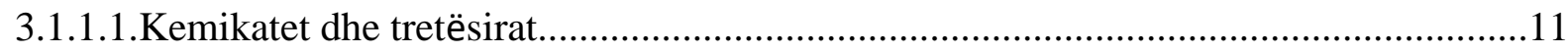

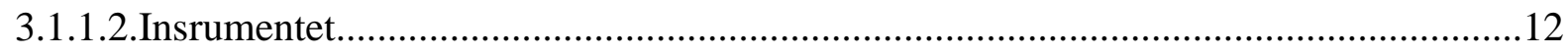

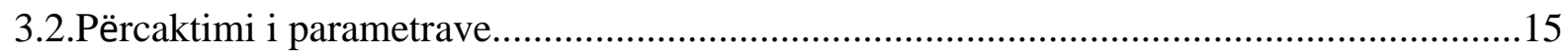

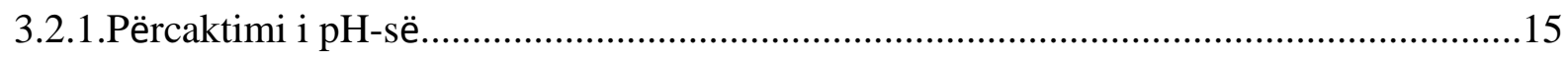

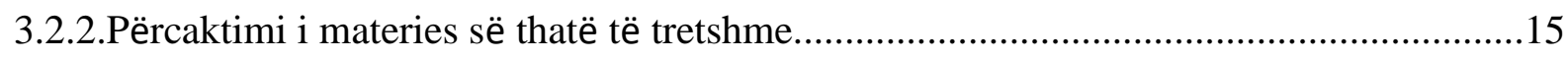

3.2.3.Përcaktimi i lagështisë............................................................................................15

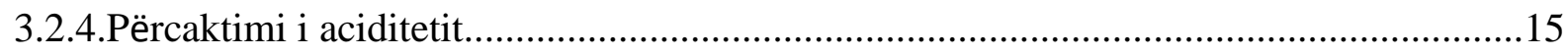

3.2.5.Përcaktimi i sheqerënave totale ................................................................................16

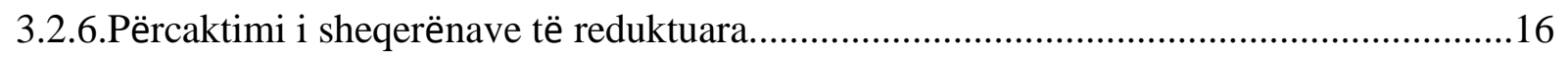

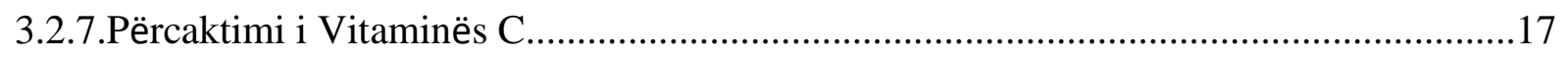

3.2.8.Përcaktimi i raportit sheqer/acid..............................................................................17

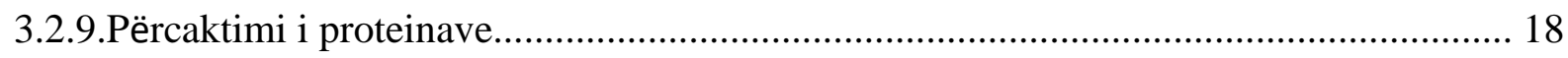

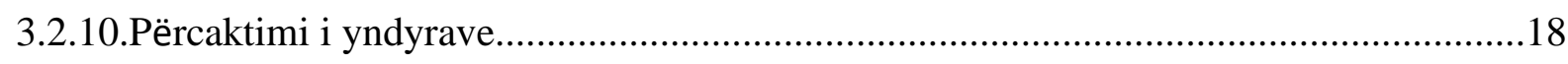

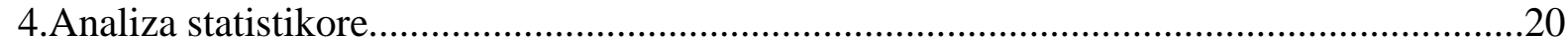

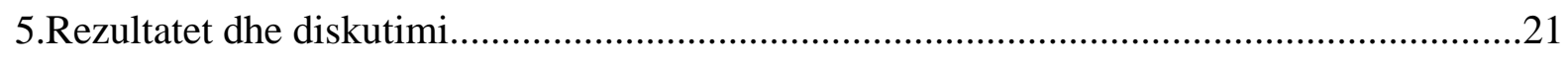

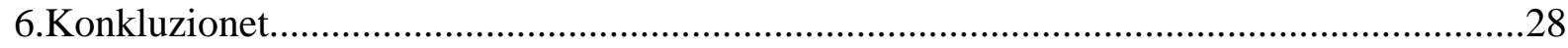

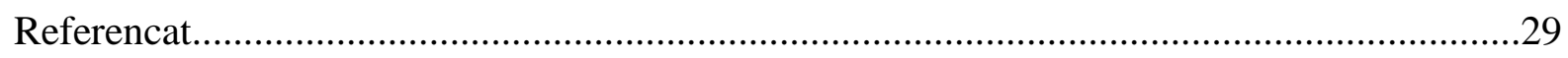




\section{LISTA E FIGURAVE}

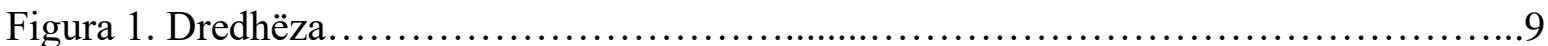

Figura 2. Përgaditja dhe analiza e mostrave të dredhëzës ...........................19

Figura 3. Ekstraktimi Solxhet i mostrave të dredhëzës...............................24

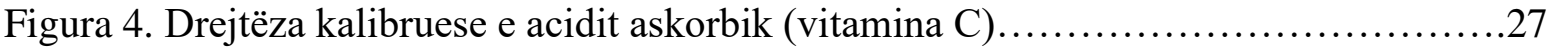

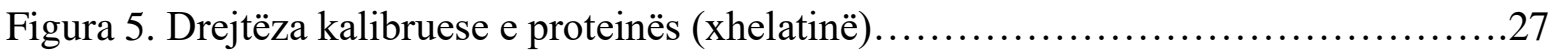

Figura 6. Drejtëza kalibruese e sheqerit (glukozë).................................28

Figura 7. Paraqitja grafike e të dhënave nga parametrat kimik dhe nutricional të dredhëzave të

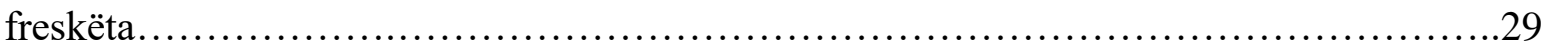

Figura 8. Vizualizimi 3D i të dhënave nga parametrat kimik dhe nutricional të dredhëzave të

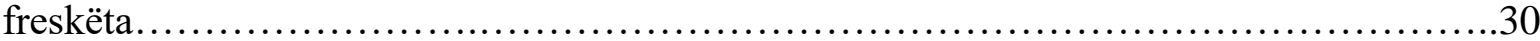




\section{LISTA E TABELAVE}

Tabela 1. Analizat kimike të dredhëzave të freskëta..................................26

Tabela 2.Vlerat nutricionale të dredhëzave të freskëta.................................26 


\section{HYRJE}

Dredhëza (Fraggaria $x$ ananassa Duch.), apo dredhëza e kopshtit si lloj i familjes së dredhëzave kultivohet kudo nëpër botë. Për shkak të vlerave ushqyese që i përmban si të tilla kontribujonë në aspektin shëndetësor dhe për këtë arsye dredhëzat mbeten si një ndër frutat me interes më të lartë për studim.Dredhëzat (Fragaria x Ananassa Duch.) janë fruta me vlerë të larta ushqyese që janë shumë të rëndësishme në dietën ushqimore ditore sepse përmbajnë nutritientë esencial që i duhen organizmit të njeriut që të funksionojnë në mënyrë të duhur (Hossain et al.,2016;Giamperi et al.,2012). Dredhëzat janë burim shumë i mirë i antioksidantëve si : polifenolet, të cilat njihen si substanca që i luftojnë radikalet e lira duke reduktuar oksidimin dhe duke i neutralizuar ato. Frutat dhe produktet e frutave janë burim natyral i mikronutritientëve dhe vitaminave, si p.sh vitamin C, mineralet, karbohidratet, fibrat, folatet dhe disa fotonutritientë të cilat janë esenciale për shëndetin e njeriut (Marinova et al.,2007).

Studimet të cilat janë zhvilluar ndër vite theksojnë se një mënyrë ushqimi e bazuar në fruta dhe perime preferohet sepse ul rrezikun për sëmundje kronike si : diabeti,infeksione,çrregullime neurologjike dhe kardiovaskulare,kancere të ndryshme (Hossain et al.,2016).Dredhëzat (Fragaria x Ananasa Duch.) konsumohen në sasi të madha si fruta të freskëta ose si produkte shtesë në industri ushqimore si : në akullore,recel,marmelladë,jogurte frutash ,lëngje etj(Liu et al.,2016). Frutat në përgjithësi si dhe dredhëzat në veçanti njihen si fruta me përmbajtje të larta të karbohidrateve( glukozë+fruktozë), por të ulëta në kalori. Përmbajnë sasi të ulëta të yndyrnave dhe proteinave, por përmbajnë sasi të larta të fibrave dietike dhe acideve organike. (Skrovankova et al.2015). Fibrat dietike dhe fruktoza kontribuojnë në rregullimin e nivelit të sheqerit në gjak duke ngadalësuar tretjen dhe duke rregulluar ndjenjën e ngopjes (Giamperi et al.,2012). Acidi askorbik ( Vitamina C) është njëri nga acidet organike me sasi më të madhe tek dredhëzat. Vlera nutricionale tek dredhëzat varet më së shumti nga përmbajtja e vitaminës C (Paz et al.,2013;Pavlovska et al.2014) që e bën dredhëzën si frut të përshtatshëm duke konsideruar përbajtjen e vitaminës $C$ dhe nevojave ushqyese të njeriut për këtë vitaminë. Karbohidratet janë komponentët kryesorë të tretshëm në frutin e pjekur të dredhëzës , me glukozën, fruktozën, saharozën duke përfshirë $99 \%$ të sheqernave totale. Sheqernat si fruktozë + glukzë luajnë rol në përcaktimin e shijes së dredhëzës dhe vlerës kalorike. Përveq 
karbohidrateve ose përkatësisht monosaharideve tek dredhëzave, acidet organike kanë ndim në shijen e frutit, në $\mathrm{pH}$, në teksturë dhe ngjyrë duke kontribuar në ndryshimet organoleptike të këtij fruti (Paz et al.,2013).

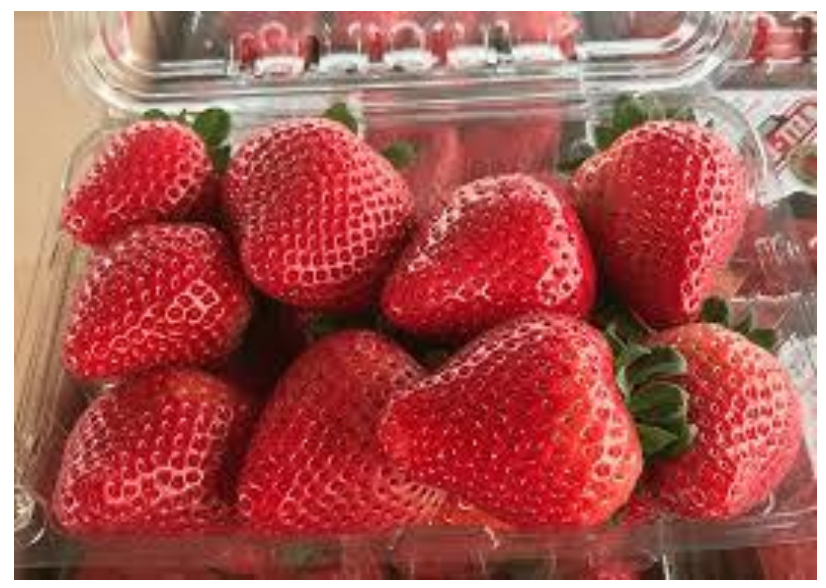

Figura 1. Dredhëza

Gjatë viteve të fundit vetëdija për konsumin e frutave dhe perimeve është rritur për shkak të ndikimit në shëndetin e njeriut duke reduktuar patologjitë kronike, obezitetin, infeksionet, sëmundjet kardiovaskulare, kancerin. (Hossain et al.,2016). Dredhëzat si fruta janë të pasura me vitamin $\mathrm{C}$, folate, antioksidantë.

Ky punim fokusohet në vlerat ushqyese të dredhzës duke u bazuar në përmbajtjen e saj dhe ndikimin në shëndetin e njeriut.Dredhëzat si fruta gjejnë përdorim të madh si të freskëta por edhe si lëndë që shtohen në produkte tjera si (jogurte, keke, akullore, recele etj.). Nga konsumtatorët dredhëzat vlerësohen sipas ngjyrës, aromës dhe konsistencës. Me ndikim të madh janë edhe këto vlerësime organoleptike që ju ndihmon konsumatorëve të vendosin për konsum të tyre. Ngjyra e dredhëzave vjen nga përmbajtja e tyre dhe nga koha e pjekjes së frutit. Aroma e dredhëzave shumë karakteristike ka zanafillën nga përmbajtja e 380 komponimeve të avullueshe që janë identifikuar që përmbajnë estere,ketone,terpene,aldehide,ketone dhe komponime që kanë sulfur.Aroma e dredhëzës vjen nga komponimet e furanolit, $\gamma$ decalaktonet, $\gamma$-dodekalactone, metil butanoate, etil butanoate, metil heksanoate, etil heksanoate, linalooli. Sa i përket shijes së dredhëzës ajo determinohet nga ekuilibri midis acidit dhe sheqerit që përmban (Perez et al.2002). 
Dredhëzat (Fragaria x Ananassa Duch.) janë shumë të përhapura në Kosovë , kultivarët e tillë zhvillohen në Kosovë duke iu përshtatur kushteve klimatike dhe nevojave që i duhen këtij fruti të rritet. Megjithatë, parametrat nutritive/ ushqyes të dredhëzave nuk janë matur në Kosovë, e as të dredhëzave që janë kultivuar në mënyrë organike.Të dhëna që përcaktojnë parametra nutritiv tek dredhëzat janë të mangëta. Ky është studimi i parë i përcaktimit të parametrave si:pH,materia e thatë e tretshme,aciditeti total,Vitamina $\mathrm{C}$,sheqernat totale, sheqernat e reduktuara, saharoza, proteinat dhe yndyrnat. 


\section{SHQYRTIMI I LITERATURËS}

\subsection{VLERAT USHQYESE TË DREDHËZËS}

Mënyra e kultivimit të dredhëzës luan rol thelbësor në vlerat ushqyese të saj. Në mënyrë që dredhëzat të kultivohen më cilësi të mirë duhet të i përshtaten kushteve që i duhen këtyre frutave. Dredhëzat si fruta kanë shumë benefite dhe si të tilla konsiderohen si zgjidhje shumë e mirë për njerëzit me sëmundje të ndryshme. Organizata Botërore e Shëndetësisë (OBSH) inkurajon konsumin e frutave dhe perimeve ndër to me theks të vecantë gjatë sezonës së kultivimit, dredhëzat të cilat janë zgjidhje shumë e mirë për kategori të sëmundjeve si diabeti, kanceri , sëmundje të zemrës.

Nga konsumtatorët dredhëzat vlerësohen sipas ngjyrës , aromës dhe konsistencës. Me ndikim të madh janë edhe këto vlerësime organoleptike që ju ndihmon konsumatorëve të vendosin për konsum të tyre. Ngjyra e dredhëzave vjen nga përmbajtja e tyre dhe nga koha e pjekjes së frutit. Aroma e dredhëzave shumë karakteristike ka zanafillën nga përmbajtja e 380 komponimeve të avullueshe që janë identifikuar që përmbajnë estere,ketone,terpene,aldehide,ketone dhe komponime që kanë sulfur.Aroma e dredhëzës vjen nga komponimet e furanolit, $\gamma$ decalaktonet, $\gamma$-dodekalactone, metil butanoate, etil butanoate, metil heksanoate, etil heksanoate, linalolin (Hossain et al.,2016;Giamperi et al.,2012). Sa i përket shijes së dredhëzës ajo determinohet nga ekuilibri midis acidit dhe sheqerit që përmban (Giamperi et al.,2012;Scalbert et al.,2005).
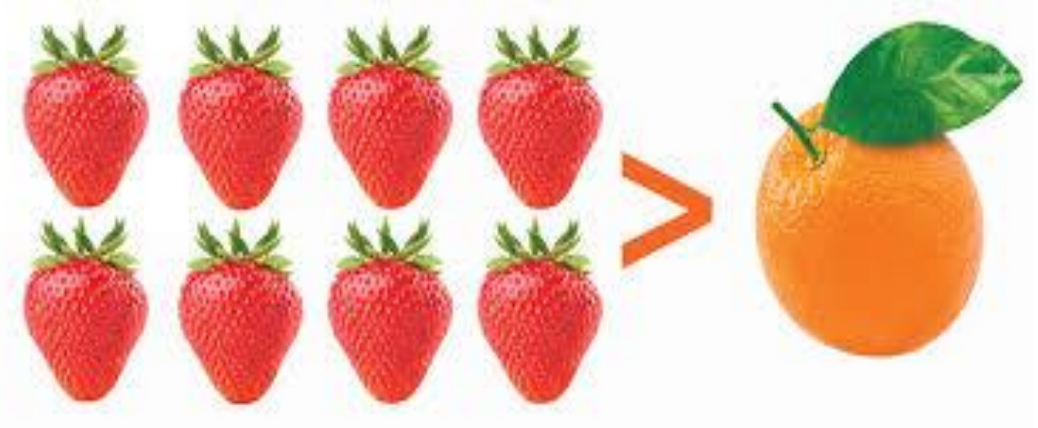


\subsection{KOMPONENTËT USHQYESE TË DREDHËZËS DHE NDIKIMI NË ORGANIZ- MIN E NJERIUT}

Sa i përket vlerave ushqyese (nutricionale) të dredhëzave njihen shumë komponime që i përbëjnë ato: Vitaminë C, kalium,fibra,acid folik.Kjo kategori e komponimeve janë pjesë përbërëse e nutrientëve esencial që i duhen trupit në mënyrë të funksionojë mirë.Në përgjithësi dredhëzat janë burim perfekt për organizmin e njeriut.Studimet tregojnë që dredhëzat janë të pasura me minerale,vitamin,folate,antioksidantë,fibra. Këta materiale luajnë rol esencial në ruajtjen e organizmit, detoksifikimin e radikaleve të lira dhe si të tilla në ruajtjen e strukturës së ADN-së ( acidit dezoksiribonukleik) që redukton mutacionet gjenetike dhe sëmundjet që pasojnë nga to (Giampieri et al. 2015).

Dredhëzat përmbajnë $(91 \%)$ ujë, $(7,7 \%)$ karbohidrate/sheqerna totale, $(0,7 \%)$ proteina,$(0,3 \%$ yndyrë). Sipas Medical News Today ( Dr.Megan) 116 gr dredhëza përmbajnë:

\begin{tabular}{|l|l|}
\hline Proteinat & $55 \mathrm{kcal}$ \\
\hline Karbohidratet & $12.75 \mathrm{gr}$ \\
\hline Proteina & $1.11 \mathrm{gr}$ \\
\hline Fibra & $3.30 \mathrm{gr}$ \\
\hline Vitaminë C & $97.60 \mathrm{mg}$ \\
\hline Magnez & $22 \mathrm{mg}$ \\
\hline Folate & $40 \mathrm{mg}$ \\
\hline Fosfor & $40 \mathrm{mg}$ \\
\hline Hekur & $0.68 \mathrm{mg}$ \\
\hline Kalcium & $27 \mathrm{mg}$ \\
\hline
\end{tabular}




\subsection{LLOJET DHE VARIETETET E DREDHËZAVE}

Lloji i dredhëzës Fragaria është e ndarë në 20 specie.Përveq këtyre llojeve të njohura njihen edhe shumë varietet dhe hibride të dredhëzës.Lloji më i përhapur dhe i hasur në kopshte dhe vendin tonë është Fragaria Annanasa Duch.

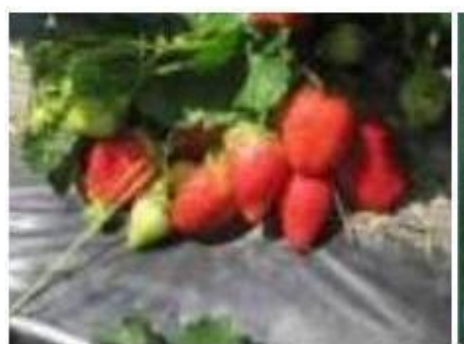

"Miss"

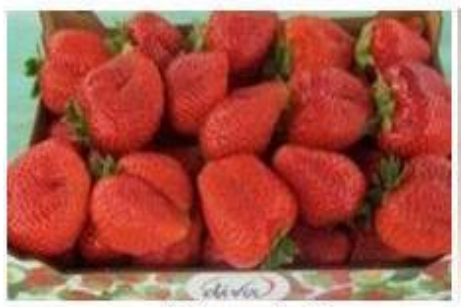

"Garda"

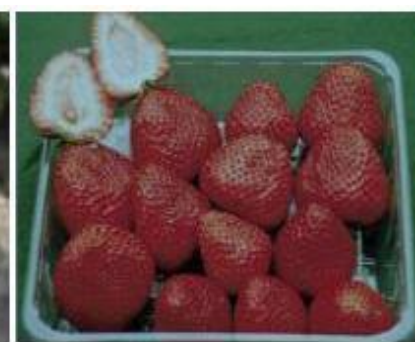

"Sugar Lia"

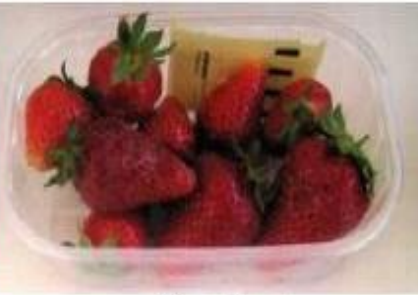

"Anita"

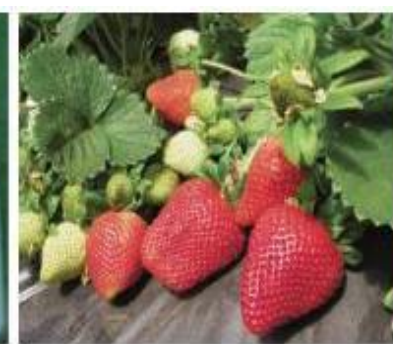

"Ventana"

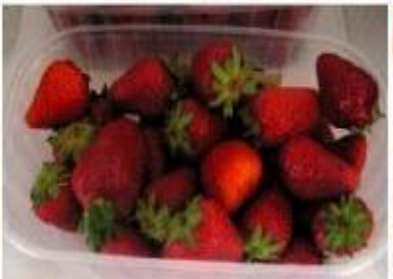

"Siba"

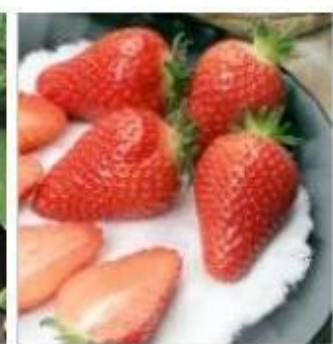

"Alba"

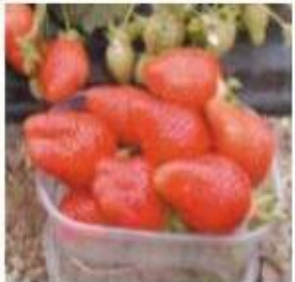

"Irma"

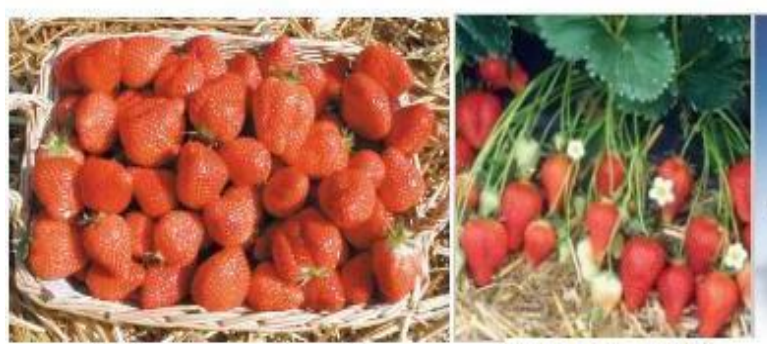

"Qeen elisa"

"Roxana"

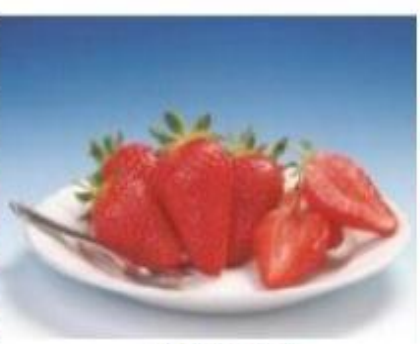

"Maya"

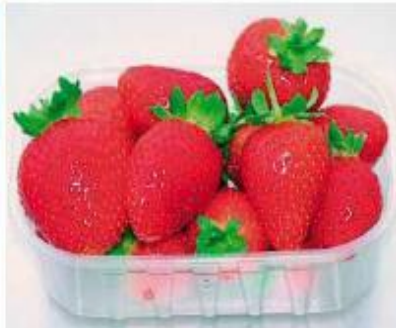

"Diamante" 


\subsection{PËRDORIMI I DREDHËZAVE}

Përveq se konsumohen si të freskëta, dredhëzat kanë përdorim të gjerë.Përdoren në industrinë e ushqimit, kimisë, farmaceutikës. Një pjesë nga prodhimi i tyre konsiderohen të i nënshtrohen metodës së tharjes për shkak se përdoren si ushqim shtesë në drithëra të ndryshme, ekstrakti i nxerrë nga dredhëza përdoret edhe si indiktatorë natyral acid/bazë , në kozmetikë përdoren në parfume,makiazhë,krema të ndryshme etj.
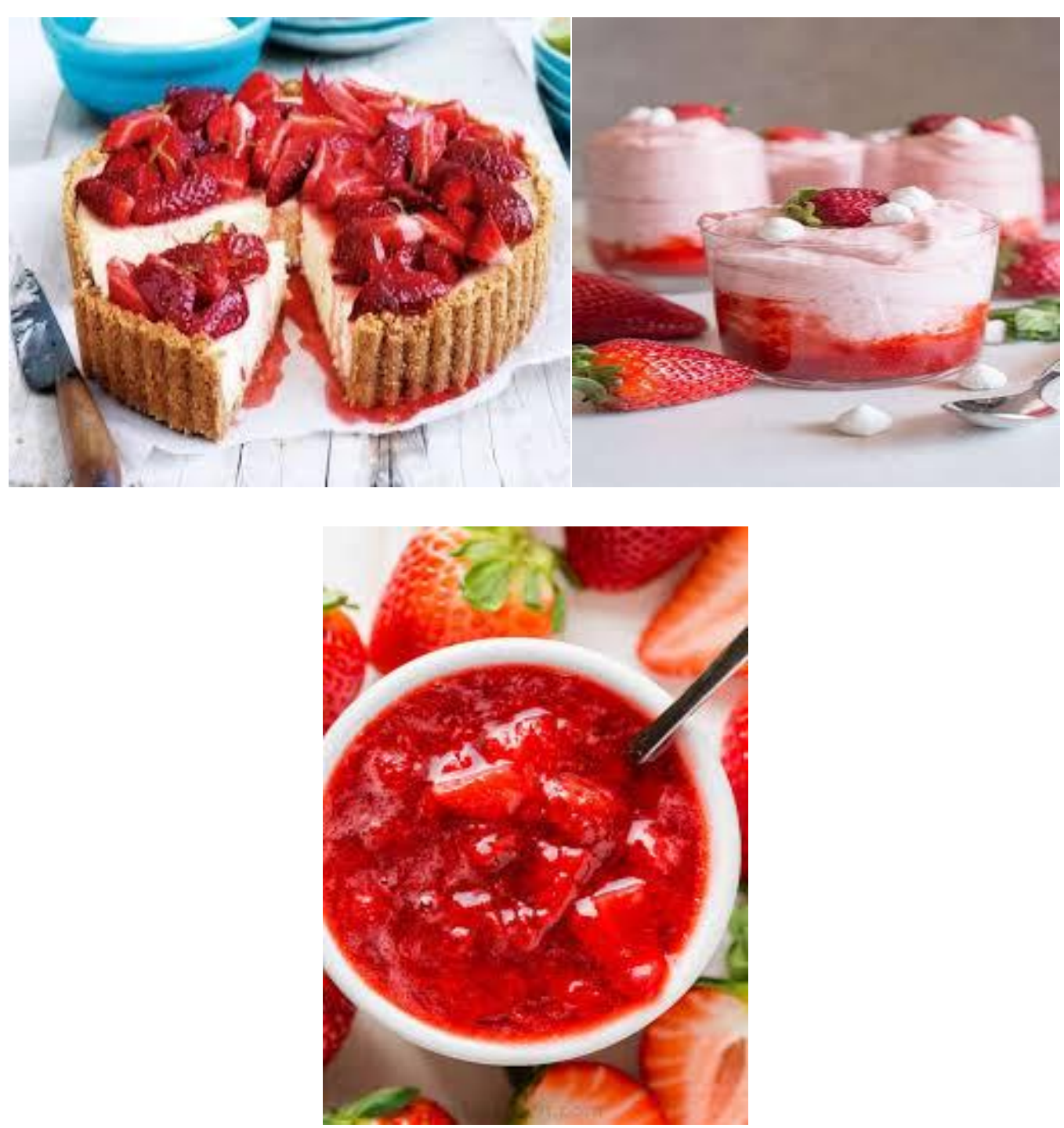


\subsection{VEPRIMI I ANTIOKSIDANTËVE}

Kapaciteti i veprimit të antioksidantëve i takon më së shumti pë rmbajtjes së vitaminave dhe polifenoleve. Për shkak të benefiteve të saj në SHBA dredhëzat rradhiten si frutat e 4-të të cilë t konsumohen më shumë (Wolfe et al.,2008). Nga shumë kultura tjera më pë rmbajtje të polifenoleve, dredhë zat janë ranguar të dytat pranë (papajës, guavës, mangos, avokados, dardhës). Dredhëzat janë të përfshira në 100 frutat dhe perimet si burim të mirë të polifenoleve duke siguruar në $1 \mathrm{mg}$ të polifenoleve totale (Perez et al.,2002). Polifenolet ndryshojnë sipas strukturës dhe funksionit të tyre dhe secila kontribuon në të mirën e shë ndetit dhe parandalimin e së mundjeve. Përmbajtja e polifenoleve në ushqime ndikon në parandalimin dhe menaxhimin e shumë c'rregullimeve duke filluar nga rregullimi i tretjes, menaxhimi i peshës, çrregullimet kardiovaskulare,diabetin etj. Përmbajtja e antioksidantëve si (polifenolet,vitamin $\mathrm{C}$, vitamin $\mathrm{E}$, karotinoidet) ruajnë indet e trupit nga stresi oksidativ që mund të shkaktojnë potencialisht kancere të ndryshme.

Dredhëzat konsiderohen si ushqime funksionale që nënkuptojnë me konsumin e tyre përfiton organizmi benefite të cilat kontribuojnë në shëndetin fizik dhe mental. Me kombinimin e nutritientëve esencial dhe përmbajtjes së fitokemikaleve,antioksidantëve dredhëza qëndron në majën e ushqimeve funsionale falë përmbajtjes që ka. Dredhëzat përmbajnë edhe tanine,fitosterole. Antocianet janë komponime të tretshme në ujë , që gjendet në bimë dhe kontribuojnë në ngjyrën e dredhëzës. Studime të ndryshme janë zhvilluar për të matur kapacitetin e antocianeve në analiza të ndryshme dhe kanë konkluduar që pë rmbajtja e tyre është shumë e lartë në dredhëza.Sipas (Aaby et al.,2007) ka identifikuar dhe kuantifikuar përmbjajtjen e antocianeve në dredhëzat e rritura dhe kultivuara në Norvegji dhe ka ranguar antocianet si kontributorët me kapacitet shumë të lartë antioksidativ.

Përmbajtja e acidit ellagjik e bën kapacitetin antioksidues shumë më të lartë, duke qenë ky acid shumë i rëndësishëm për trajtimin e agjentëve viral, bakterial dhe parandalimin e kancereve të ndryshme.Ky acid esencial për trupin e njeriut gjendet në shumë pak produkte, por dredhëzat përmbajnë sasi të lartë të tij. Duke krahasuar përmbajtjen e acidit ellagjik me frutat e tjerë, dredhëzat përmbajnë 17mg/100 gram të frutave të freskëta të dredhëzës (Bakkalbasi et al,.2009; Aaby et al.,2007). 
Përmbajtja e flavonoideve si (katehina,kuerketina,kampferoli, naringenina,hesperidina kanë strukturë kimike të ndryshme dhe janë të pranishme në ushqimet me prejardhje bimore. Aktiviteti i radikaleve të lira është treguar i suksesshëm me praninë e flavonoideve. Të tilla komponime aktive natyrale janë identifikuar në dredhëza. 


\section{PJESA EKSPERIMENTALE}

\section{METODOLOGJIA}

\subsection{METODAT DHE TEKNIKAT E PËRDORURA}

Mostrat e dredhëzave (Fragaria x Ananassa Duch.) janë marrë nga 4 kultivarë të cilat janë rritur në plantacione të ndryshme në Kosovë në fazën e fundit të pjekjes në qershor 2019. Mesatarisht janë marrë $1 \mathrm{~kg}$ dredhëza me ngjyrë të kuqe të ndritur nga kopshti dhe janë transferuar në laboratoret e UBT-së ditën e marrjes së mostrave dhe janë ruajtur në temperaturë $+4{ }^{\circ} \mathrm{C}$. Me analizat kemi vazhduar ditën e nesërme. Frutat e dredhzës janë pastruar me ujë të rrjedhshëm,pastaj me ujë të distiluar, dhe pas larjes janë tharë duke vazhduar me bluarjen e mostrave duke përdorur havanin shtypës. Mostrat janë bërë gati për analiza të rradhës. Nga mostra e plotë janë marrë 3 nënmostra me të cilat janë analizuar.

Vlerat ushqyese të dredhzës janë përcaktuar duke analizuar parametrat kimik si: $\mathrm{pH}$, materia e thatë e tretshme ${ }^{\circ}$ Brix , lagështia, aciditeti total,Vitamina $\mathrm{C}$, sheqernat totale, sheqernat e reduktuara, saharoza, proteinat dhe yndyrat. Parametrat e lartëcekura tregojnë për cilësinë e dredhëzës dhe përmbajtjen e saj.Përcaktimi i vlerave ushqyese përmes këtyre parametrave ëshë analizuar sipas metodave standarde të AOAC 2016.

\subsubsection{METODAT}

\section{Spektrofotometria}

Spektrofotometria është metodë e absorbimit, e cila bazohet në hulumtimin e varësisë së absorbancës nga gjatësia valore e rrezës,e cila kalon përmes substancës analizuese.Spektrofotometria,fotometria dhe kolorimetria janë variante të ndryshme të analizës spektrale absorbcionometrike të bazuara në ligjin e Beerit.Ligji i Beerit përshkruan absorbimin karakteristik të tufës së rrezeve rënëse monokromatike dhe paralele në mesin homogjen dhe izotrop.Formulimi përfundimtar i thjeshtuar i ligjit të Beerit matematikisht shprehet: 


\section{$A=\varepsilon \mathbf{x c x b}$}

$\mathrm{Ku}:$

A-paraqet absorbancën,

$\boldsymbol{\varepsilon}$-koeficientin molar të absorbimit,

c-përqendrimin dhe

b-trashësinë e shtresës

Ligji i Beerit, në mënyrë eksplicite,paraqet varësinë lineare në mes absorbancës dhe përqendrimit të molekulave absorbuese në tretësirë.Ky ligj kryesisht vlenë për rrezatim monokromatik.Nëse në tretësirën analizuese përqendrimi ndryshon për shkak të protolizës,dimerizimit,solvatimit,tautomerizmit,etj.atëherë kemi shmangie nga ky ligj.Spektrofotometria e absorbimit bazohet në matjen e absorbimit të rreztimit monokromatik në regjionin spektral UV-VIS.Spektrofotometrat UV-VIS janë të paisur me llampën e volframit, të hidrogjenit ose me atë të deuteriumit.Si detektor zakonisht përdoren gypat fotomultiplikator me senzorë përkatës për leximin e A ose \% T.

\subsubsection{Kemikatet dhe tretësirat}

Të gjitha tretësirat e nevojshme,për zhvillimin e analizave të parametrave kimik të dredhëzës,janë përgaditur nga kemikatet analitikisht të pastra (p.a.) duke i tretur ato në ujë të distiluar.Në punën eksperimentale kemi përdorur këto kemikate (nga prodhues të ndryshëm si: "Alkaloid", ,'Honeywell",,Sigma" etj.) dhe tretësira :

$>$ Permanganati i kaliumit

Acidi askorbik

$>$ Hidroksidi natriumit

$>$ Fenolftaleina

$>$ Acidi sulfurik

$>$ Petroleum eter

$>$ Xhelatinë 
$>$ Tretësirat e Fehlingut I dhe II

$>$ Fenol

$>$ Glukozë

Të gjitha tretësirat janë përgaditur duke e tretur sasinë e nevojshme të substancës përkatëse dhe me hollimin deri në vëllimin e caktuar me ujë të distiluar.

\subsubsection{INSTRUMENTET}

Gjatë punës eksperimentale kemi përdorur këto instrumente:

> Spektrofotometer UV-VIS Genesys 10S

$>\mathrm{pH}$ metër

$>$ refraktotmetër

$>$ Si mjete ndihmëse kanë shërbyer:

$>$ Peshorja analitike

$>$ Enët matëse (vegeglas)

$>$ Eksikatori me $\mathrm{CaO}$

$>$ Tertore

> Aparatura komplete për distilimin e ujit

$>$ Enë normale $10 \mathrm{~mL}, 25 \mathrm{~mL}, 50 \mathrm{~mL}, 100 \mathrm{~mL}, 250 \mathrm{~mL}, 500 \mathrm{~mL}$

$>$ Erlenmajera $100 \mathrm{~mL}, 250 \mathrm{~mL}$

$>$ Byreta $50 \mathrm{~mL}$

$>$ Gota laboratorike $50 \mathrm{~mL}, 100 \mathrm{~mL}, 250 \mathrm{~mL}$

$>$ Letër filtruese kualitative dhe kuantitative 

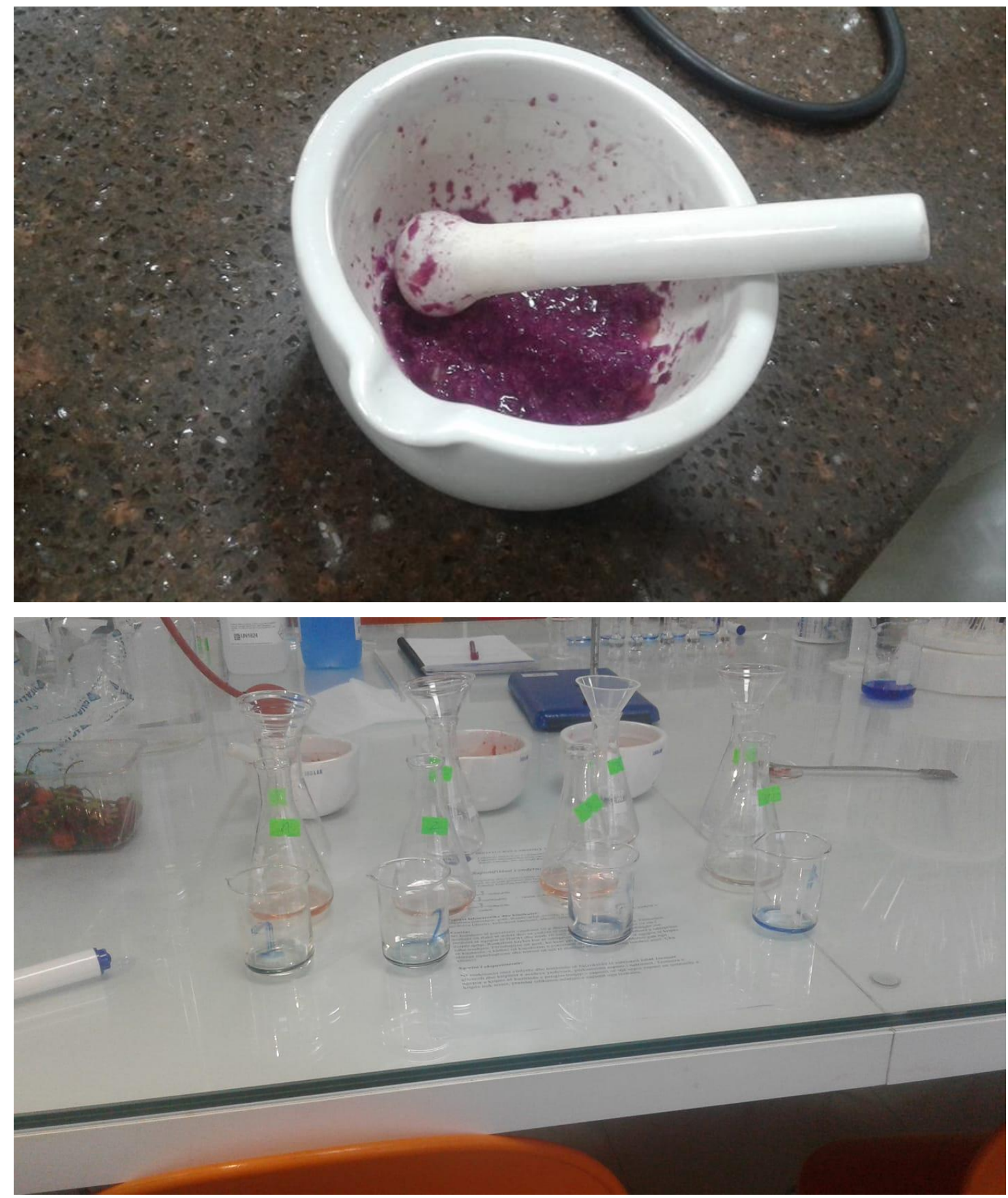

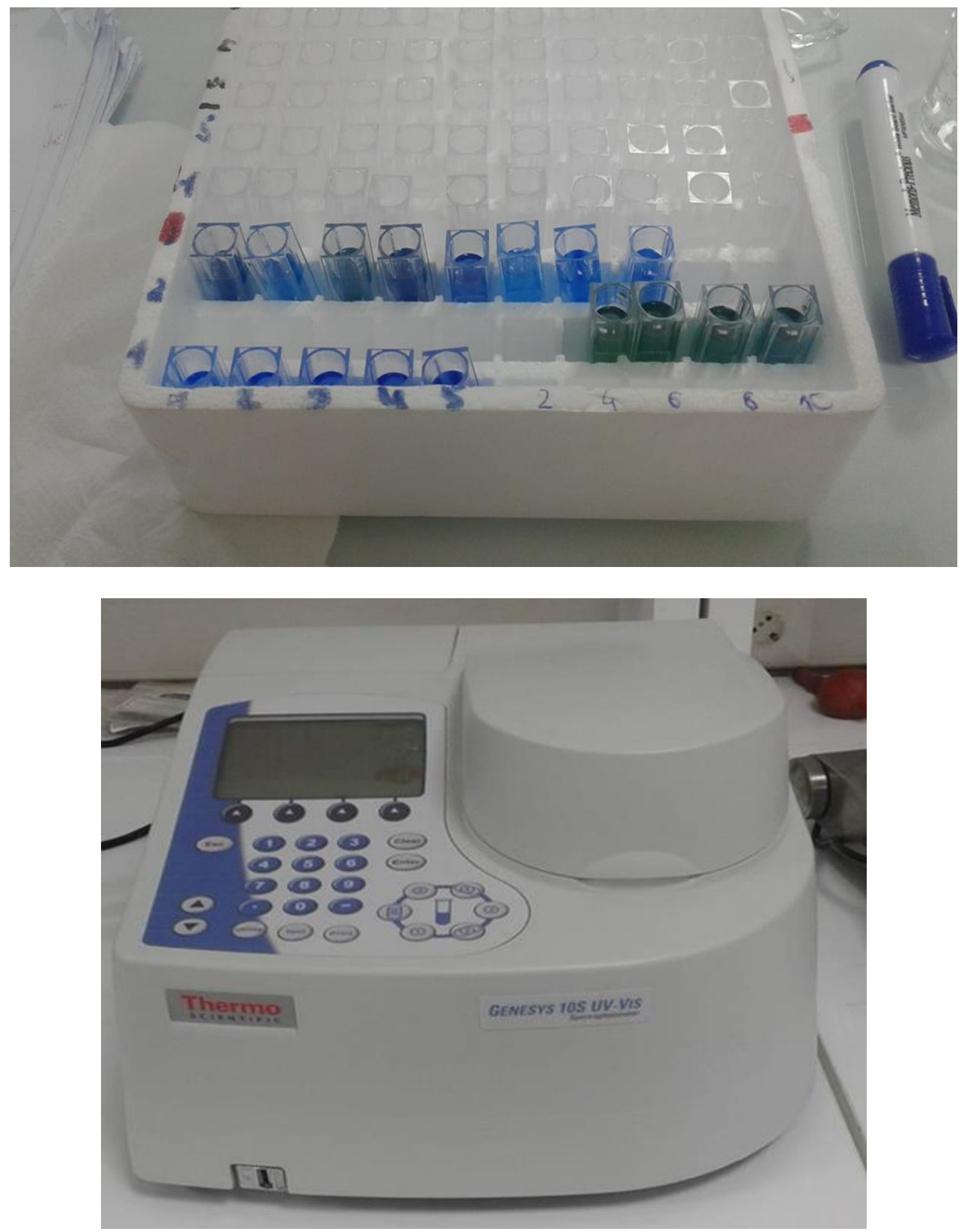

Figura 2.Përgaditja dhe analiza e mostrave të dredhëzës 


\subsection{PËRCAKTIMI I PARAMETRAVE}

\subsubsection{PËRCAKTIMI I pH-së}

pH e mostrave është përcaktuar duke përdorur pH metër digjital.pH metri është kalibruar para matjeve duke përdorur tretësira puferike me $\mathrm{pH} 4$ dhe $7 . \mathrm{pH}$ matet direkt duke vendosur elektrodën e pH metrit në gotë laboratorike ku kemi vendosur paraprakisht $5 \mathrm{~mL}$ tretësirë të mostrës për analizë.

\subsubsection{PËRCAKTIMI I MATERIES SË THATË Tё TRETSHME ( ${ }^{\circ}$ Brix)}

Materia e thatë e tretshëme u përcaktua duke përdorur refraktometrin Abbe në $20^{\circ} \mathrm{C}$ sipas metodës standarde (AOAC, 2016). Refraktometri është i lidhur me termometër për kontrollin e temperaturës, dhendizet burimi i dritës ndezur para përcaktimit. Refraktometri u pastrua me ujë të distiluar para se pikat e mostrave të vendoseshin në xhamin e refraktometrit dhe kapaku të mbyllej dhe lexohet materia e thatë e tretshme e mostrave në shkallë brix ( ${ }^{\circ}$ Brix).

\subsubsection{PËRCAKTIMI I LAGËSHTISË. METODA ME THARJE NË FURRË NË 105C}

Kjo metodë bazohet në tharjen e produktit të vendosur në furrë, në tempëraturë $105^{\circ} \mathrm{C}$ për 2 orë. Në fillim peshohen enët e thata pastaj vendosen mostrat dhe maten me mostra në peshore analitike dhe në fund pas tharjes maten në peshore analitike.

Lagështia llogaritet sipas ekuacionit :

\section{$\%$ lagështisë $=M_{1}-M_{2} / P \times 100$}

$\mathbf{M}_{1}=\operatorname{Masa}(\mathrm{g})$ e enës me mostër para tharjes ;

$\mathbf{M}_{2}=$ Pesha $(\mathrm{g})$ e mostrës pas tharjes dhe

$\mathbf{P}=$ Masa e produktit.

\subsubsection{PËRCAKTIMI I ACIDITETIT}

Metoda për përcaktimin e aciditetit që e kemi përdor është titrimi i mostrës me $\mathrm{NaOH}$ me përqendrim 0,1 mol/dm duke përdorur indikatorin fenolftaletin. Nga mostra ndahet $1 \mathrm{~g}$ të cilat treten në $10 \mathrm{ml}$ ujë të distiluar, titrohet me $\mathrm{NaOH}$ me $\mathrm{c}=0,1 \mathrm{~mol} / \mathrm{dm}$ deri në ndryshimin e ngjyrës. 
Sasia e aciditetit në mostër e shprehur në përqindjen e acidit citrik llogaritet sipas ekuacionit:

\section{$\%$ Aciditeti $=\mathrm{C}_{(\mathrm{NaOH})} \times \mathbf{V}_{(\mathrm{NaOH})} \times \mathrm{M}_{(\text {acid citrik) }} /$ Masa e mostrës}

\subsubsection{PËRCAKTIMI I SHEQERËNAVE TOTALE}

Tek produktet me prejardhje bimore karbohidratet janë përbërësit kryësor.Sheqernat të cilat janë në sasi më të madhe janë : glukozë,fruktozë,saharozë.Metodën të cilën e kemi përdor është me anë të acidit fenol acid sulfurik (Nielsen,2009). Glukoza është përdorur për ndërtimin e drejtzës kaliburese dhe matja e absorbancës është bërë në $490 \mathrm{~nm}$.

Tretësirat standarde glukozës është përgaditur duke tretur 0,1 gram glukozë në $100 \mathrm{~cm}^{3}$ ujë të distiluar,pastaj është përgaditur seria standarde me 5 hollime duke filluar nga $1 \mathrm{~mL}, 3 \mathrm{~mL}, 5 \mathrm{~mL}, 7 \mathrm{~mL}, 9 \mathrm{~mL}$ dhe duke i tretur në enë normale $10 \mathrm{~mL}$ dhe nivelizuar me ujë të distiluar deri në shenjë.Reagjentët të cilët janë fenol dhe acid sulfurik të cilët shtohe në mostrat e filtruara dhe matet absorbanca.

Kurse, sasia e saharozës është përcaktuar duke kalkuluar diferencën mes sheqernave totale dhe sheqernave të reduktuara.

\subsubsection{PËRCAKTIMI I SHEQERNAVE TË REDUKTUARA}

Përcaktimi i sheqernave të reduktuar ëshë bërë me metodën Lan-Enjon si dhe tretësirat e Fehlingut të cilat janë të bazuara sipas standardit AOAC 2016.

Në erlenmajer vendoset $5 \mathrm{~mL}$ mostër e filtruar dhe e holluar me ujë të distiluar deri në 15 $\mathrm{mL}$.Shtojmë $15 \mathrm{~cm}^{3}$ të tretësirës nga bureta që përmban tretësirat standarde Fehling I dhe Fehling II dhe shënojmë ngjyrën e përzierjes. Vendoset erlenmajeri në një pllakë të nxehtë dhe përzierja vlonë jo më shumë se 2 minuta.Nëse ngjyra origjinale vazhdon pasi të vlojë për 1015 sekonda, tregon se shumica e tretësirës Fehling nuk është zvogëluar ende dhe vazhdon titrimi deri në paraqitjen e ngjyër së portokallët.Shtojmë tre ose katër pika të indikatorit metilen blu dhe vazhdon titrimi, derisa ngjyra të ndryshojë nga blu në të njëjtën pamje të ndritshme portokalli që kishte përpara shtimit të indikatorit metilen blu. Nxehet tretësira në erlenmajer për 2 minuta. Shtojmë tre ose katër pika të indikatorit metilen blu dhe vazhdon titrimi derisa 
tretësira të bëhet e pangjyrë. Titrimi duhet të përfundojë brenda 3 minutave dhe gjatë kësaj kohe përzierja duhet të mbahet duke përzier vazhdimisht për të përjashtuar ajrin.

Sasia e sheqerënave të reduktuar llogaritet sipas ekuacionit:

$\%$ Sheqer i reduktuar $=$ Faktori i tretësirës Fehling $\times$ Vëllimi $\times 100 /$ Titrin $\times$ masa e mostrës $\times$ mL tretësirës

\subsubsection{PËRCAKTIMI I VITAMINËS C}

Dredhëzat si fruta kanë përmbajtje të lartë të vitaminës C. Vitamina C është e tretshme në ujë dhe nuk sintetizohet nga organizmi dhe si e tillë duhet të merret me anë të ushqimit. Kjo vitaminë ëshrë shumë e rëndësishme për organizmin duke qenë një antioksidant i fuqishëm , mbron sistemin imunitar dhe ruan shëndetin e qelizave në trup. Vitamina $\mathrm{C}$ gjendet në sasi të madhe tek dredhëzat dhe gjatë sezonës së kultivimit të tyre dredhëzat janë opsion i përshtatshëm i burimit të kësaj vitamine.

Metoda që kemi përdor për matjen e kesaj vitamine është spektofotometri UV-VIS duke matur përqëndimin dhe absorbancën e mostrave. Reagjenti i cili është përdorur është permanganati i kaliumit që në bashkëveprim me vitaminën $C$ jep një kompleks të tretshëm me ngjyrë vjollce intenzive dhe absorbanca e tretësirës matet në $530 \mathrm{~nm}$ pas qëndrimit 10 minuta.

Tretësirat standarde acidit askorbik është përgaditur duke tretur 0,1 gram acid askorbik në

$100 \mathrm{~cm}^{3}$ ujë të distiluar,pastaj është përgaditur seria standarde me 5 hollime duke filluar nga $1 \mathrm{~mL}, 3 \mathrm{~mL}, 5 \mathrm{~mL}, 7 \mathrm{~mL}, 9 \mathrm{~mL}$ dhe duke i tretur në enë normale $10 \mathrm{~mL}$ dhe nivelizuar me ujë të distiluar deri në shenjë.Reagjenti i cili është përdorur është permanganati i kaliumit shtohet në mostrat e filtruara dhe matet absorbanca.

\subsubsection{PËRCAKTIMI I RAPORTIT SHEQER/ACID}

Raporti sheqer / acid kontribuon në dhënien e shumë frutave aromën e tyre karakteristike dhe është një tregues i pjekurisë tregtare dhe organoleptike. Në fillim të procesit të pjekjes, raporti sheqer / acid është i ulët, për shkak të përmbajtjes së ulët të sheqerit dhe përmbajtjes së lartë të acideve frutore, kjo e bën frutin me shije. Gjatë procesit të pjekjes acidet e frutave degradohen, 
përmbajtja e sheqerit rritet dhe raporti sheqer / acid arrin vlerë më të lartë. Frutat tepër të pjekura kanë nivele shumë të ulëta të acidit frutor dhe për këtë arsye u mungon aroma karakteristike. Raporti sheqer/acid në mostër është përcaktuar duke llogaritur nga ekuacioni:

\section{Sheqer $/$ acid $=$ TSS $(\circ$ Brix $) / \%$ TA}

\subsubsection{PËRCAKTIMI I PROTEINAVE}

Tek dredhëzat, proteinat janë në sasi mjaft të vogël duke përfshi $0.3-0.7 \%$ totale.Metoda që është përdor për matje e proteinave është meoda Bredford me disa modifikime.Absorbanca matet në gjatësi valore 545nm duke përdorur xhelatinën si tretësirë standarde.

Tretësirat standarde xhelatinë është përgaditur duke tretur 0,1 gram xhelatinë në $100 \mathrm{~cm}^{3}$ ujë të distiluar,pastaj është përgaditur seria standarde me 5 hollime duke filluar nga $1 \mathrm{~mL}, 3 \mathrm{~mL}, 5 \mathrm{~mL}, 7 \mathrm{~mL}, 9 \mathrm{~mL}$ dhe duke i tretur në enë normale $10 \mathrm{~mL}$ dhe nivelizuar me ujë të distiluar deri në shenjë.Reagjenti i cili është përdorur është reagjenti i Biuretit ( Fehling 1 dhe Fehling 2) shtohet në mostrat e filtruara dhe matet absorbanca.

\subsubsection{PËRCAKTIMI I YNDYRAVE}

Tek dredhëzat gjendet sasi e vogël e yndyrave,që i bënë shumë të përshtatshme për konsum në dietat ushqimore.Metoda që është përdorur për ta ekstraktuar yndyrën është metoda e Solxhetit.Fillimisht,merren 5 gram mostër dhe vendosen në aparaturën solxhet dhe si tretës është përdorur petroleteri.Pas ekstraktimit sasia e yndyrës matet. 


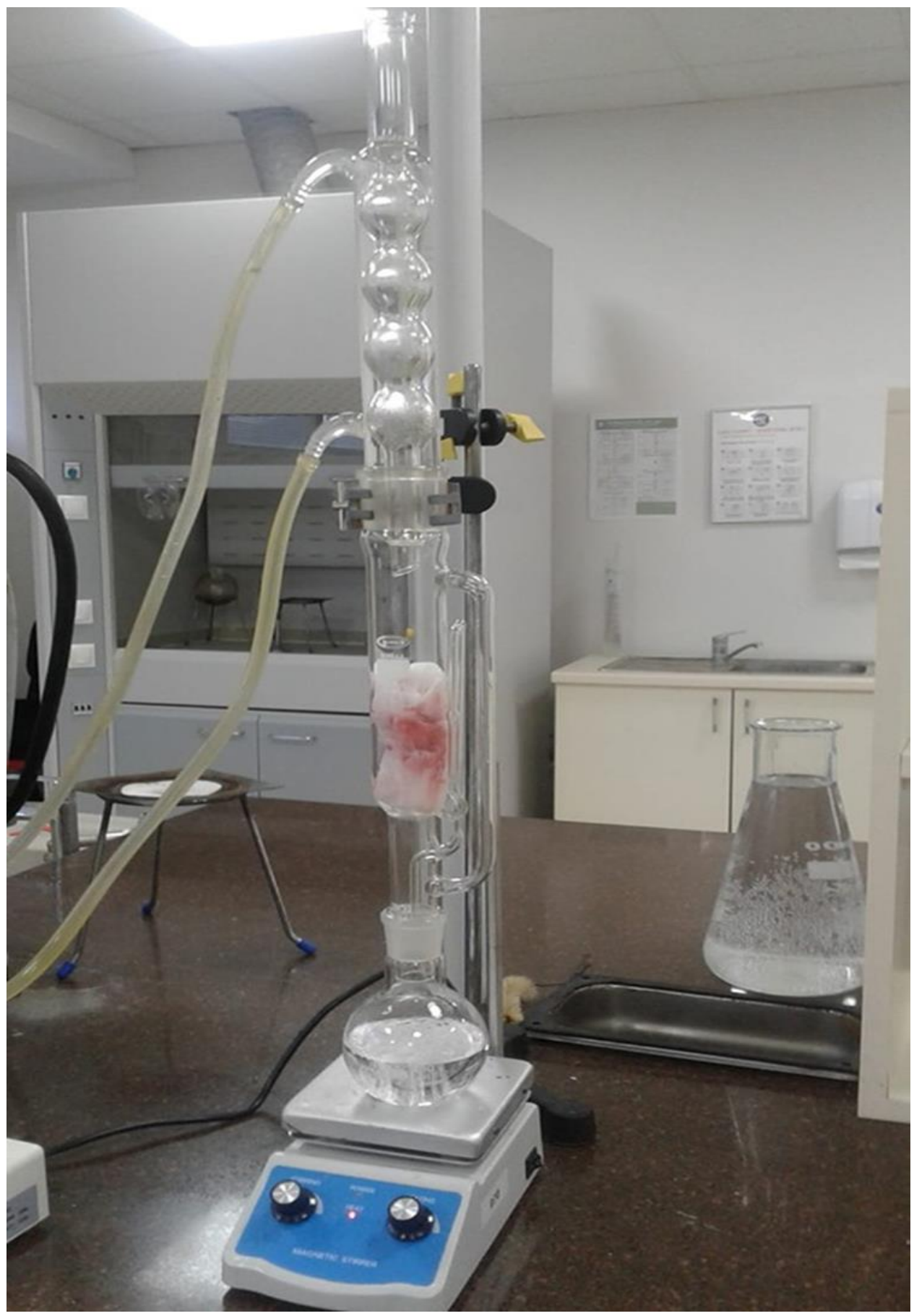

Figura 3.Ekstraktimi Solxhet i mostrave të dredhëzës 


\section{ANALIZAT STATISTIKORE}

Të gjitha të dhënat janë paraqitur si vlerë mesatare \pm dhe devijimi standard të eksperimenteve të trefishta. Të gjitha analizat statistikore janë përcaktuar me përdorimin e programit MS EXCEL dhe softwerit për statistika SPSS 22.0. Dallimet janë rishikuar për shkak të saktësisë duke përdorur metodën ANOVA, me nivel të saktësisë $\mathrm{p}<0.05$. 


\section{REZULTATET DHE DISKUTIMI}

Rezultatet e analizave kimike dhe nutricionale nga mostrat e dredhëzave të freskëta janë analizuar gjatë periudhës së Qershorit 2019, nga katër kultivarë të ndryshëm të cilat janë paraqitur në Tabelat 1-2.

Tabela 1. Analizat kimike të dredhëzave të freskëta

\begin{tabular}{|l|l|l|l|l|l|}
\hline Sample & pH & $\mathbf{W}(\mathbf{D M}) / \%$ & TSS/Brix & TA/ \% & $\begin{array}{l}\text { TSS/TA } \\
\text { ratio }\end{array}$ \\
\hline $\mathrm{S}_{1}$ & $4.10 \pm 0.2$ & $3.03 \pm 0.1$ & $9.00 \pm 0.1$ & $0.95 \pm 0.1$ & $9.47 \pm 0.1$ \\
\hline $\mathrm{S}_{2}$ & $3.80 \pm 0.2$ & $1.47 \pm 0.1$ & $9.00 \pm 0.1$ & $0.76 \pm 0.1$ & $11.84 \pm 0.2$ \\
\hline $\mathrm{S}_{3}$ & $3.85 \pm 0.1$ & $1.96 \pm 0.1$ & $8.00 \pm 0.1$ & $0.72 \pm 0.2$ & $11.11 \pm 0.2$ \\
\hline $\mathrm{S}_{4}$ & $4.30 \pm 0.1$ & $3.04 \pm 0.1$ & $5.00 \pm 0.1$ & $0.90 \pm 0.2$ & $5.55 \pm 0.2$ \\
\hline
\end{tabular}

Të dhënat janë paraqitur si vlera mesatare \pm të devijimit standard të tri mostrave

Tabela 2. Vlerat nutricionale të dredhëzave të freskëta

\begin{tabular}{|l|l|l|l|l|l|l|}
\hline Sample & $\begin{array}{l}\text { Vitamin } \\
\text { C } \\
\mathbf{m g} / \mathbf{1 0 0 g}\end{array}$ & $\begin{array}{l}\text { Total } \\
\text { sugars } \\
\mathbf{g} / \mathbf{1 0 0 g}\end{array}$ & $\begin{array}{l}\text { Reducing } \\
\text { sugars } \\
\mathbf{g} / \mathbf{1 0 0 g}\end{array}$ & $\begin{array}{l}\text { Sucrose } \\
\mathbf{g} / \mathbf{1 0 0 g}\end{array}$ & $\begin{array}{l}\text { Lipids } \\
\mathbf{g} / \mathbf{1 0 0 g}\end{array}$ & $\begin{array}{l}\text { Proteins } \\
\mathbf{g} / \mathbf{1 0 0 g}\end{array}$ \\
\hline $\mathrm{S}_{1}$ & $56.7 \pm 0.1$ & $2.17 \pm 0.1$ & $1.97 \pm 0.2$ & $0.20 \pm 0.2$ & $0.25 \pm 0.1$ & $0.73 \pm 0.1$ \\
\hline $\mathrm{S}_{2}$ & $54.18 \pm 0.3$ & $2.05 \pm 0.3$ & $1.79 \pm 0.1$ & $0.26 \pm 0.3$ & $0.22 \pm 0.2$ & $0.80 \pm 0.1$ \\
\hline $\mathrm{S}_{3}$ & $52.44 \pm 0.3$ & $2.04 \pm 0.1$ & $1.75 \pm 0.1$ & $0.29 \pm 0.1$ & $0.22 \pm 0.1$ & $0.84 \pm 0.2$ \\
\hline $\mathrm{S}_{4}$ & $50.57 \pm 0.1$ & $2.82 \pm 0.1$ & $2.47 \pm 0.1$ & $0.35 \pm 0.1$ & $0.28 \pm 0.2$ & $0.69 \pm 0.3$ \\
\hline
\end{tabular}

Të dhënat janë paraqitur si vlera mesatare \pm të devijimit standard nga tri mostrat 


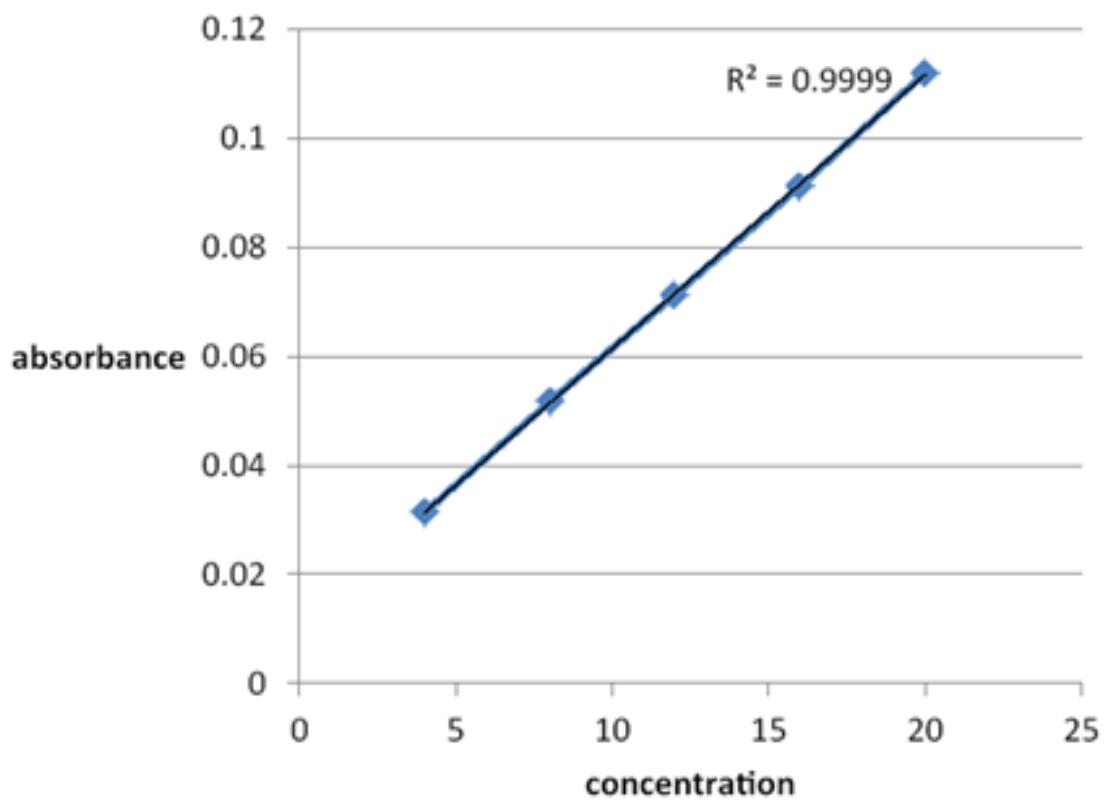

Figura 4.Drejtëza kalibruese e acidit askorbik (vitamina C)

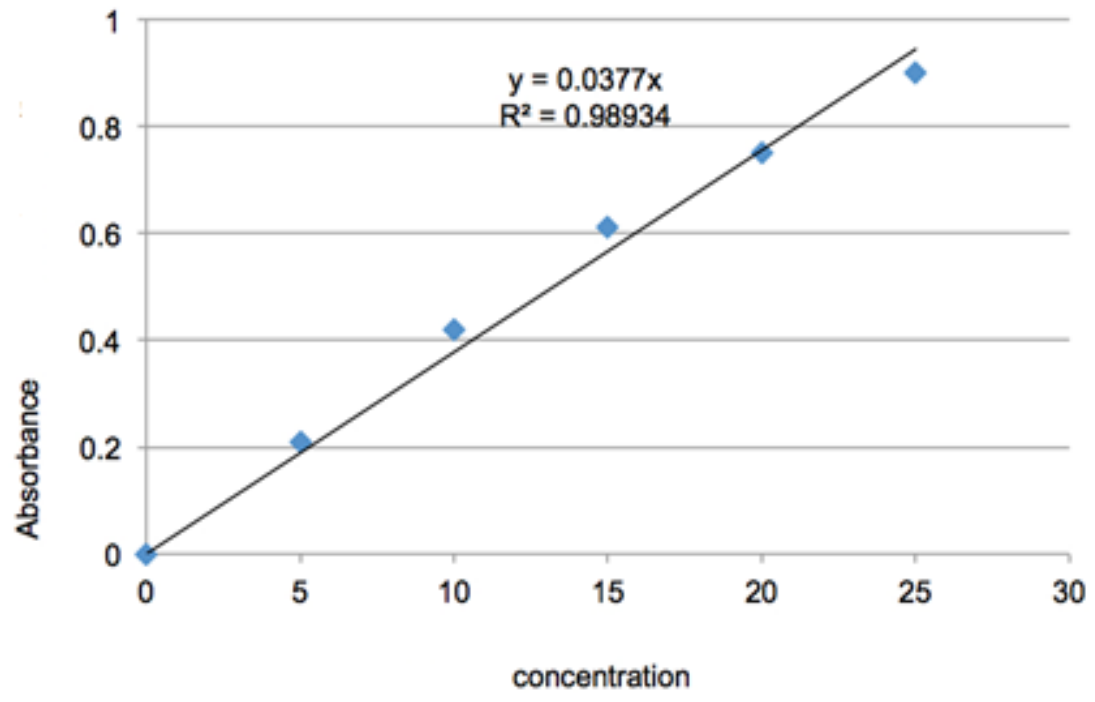

Figura 5.Drejtëza kalibruese e proteinës (xhelatinë) 


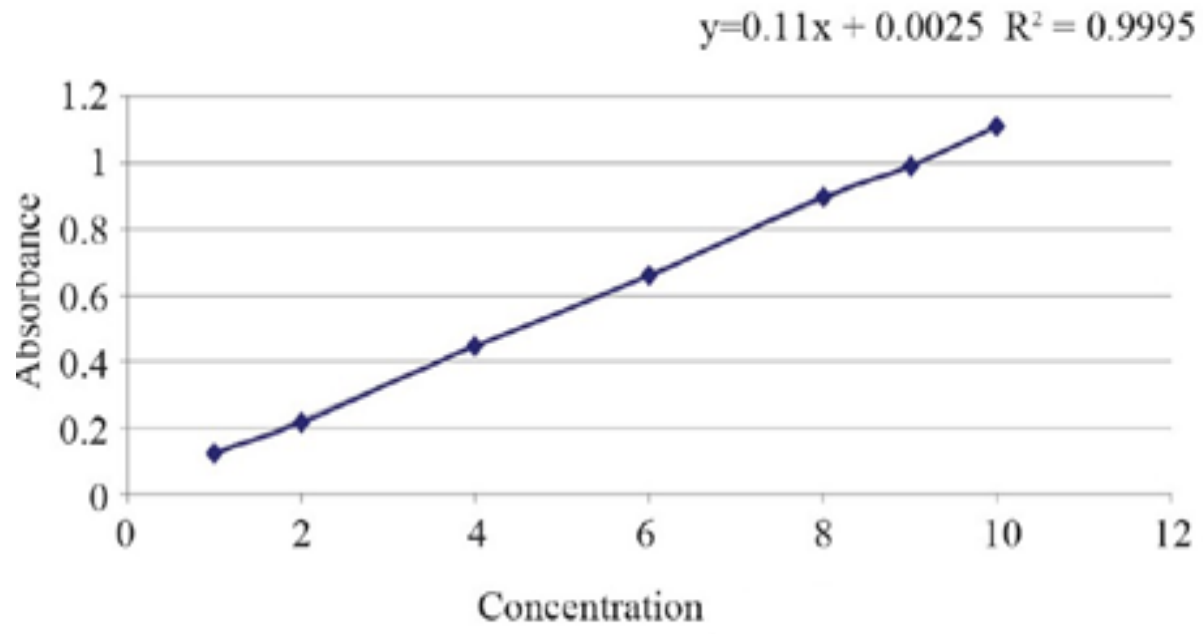

Figura 6.Drejtëza kalibruese e sheqerit (glukozë) 


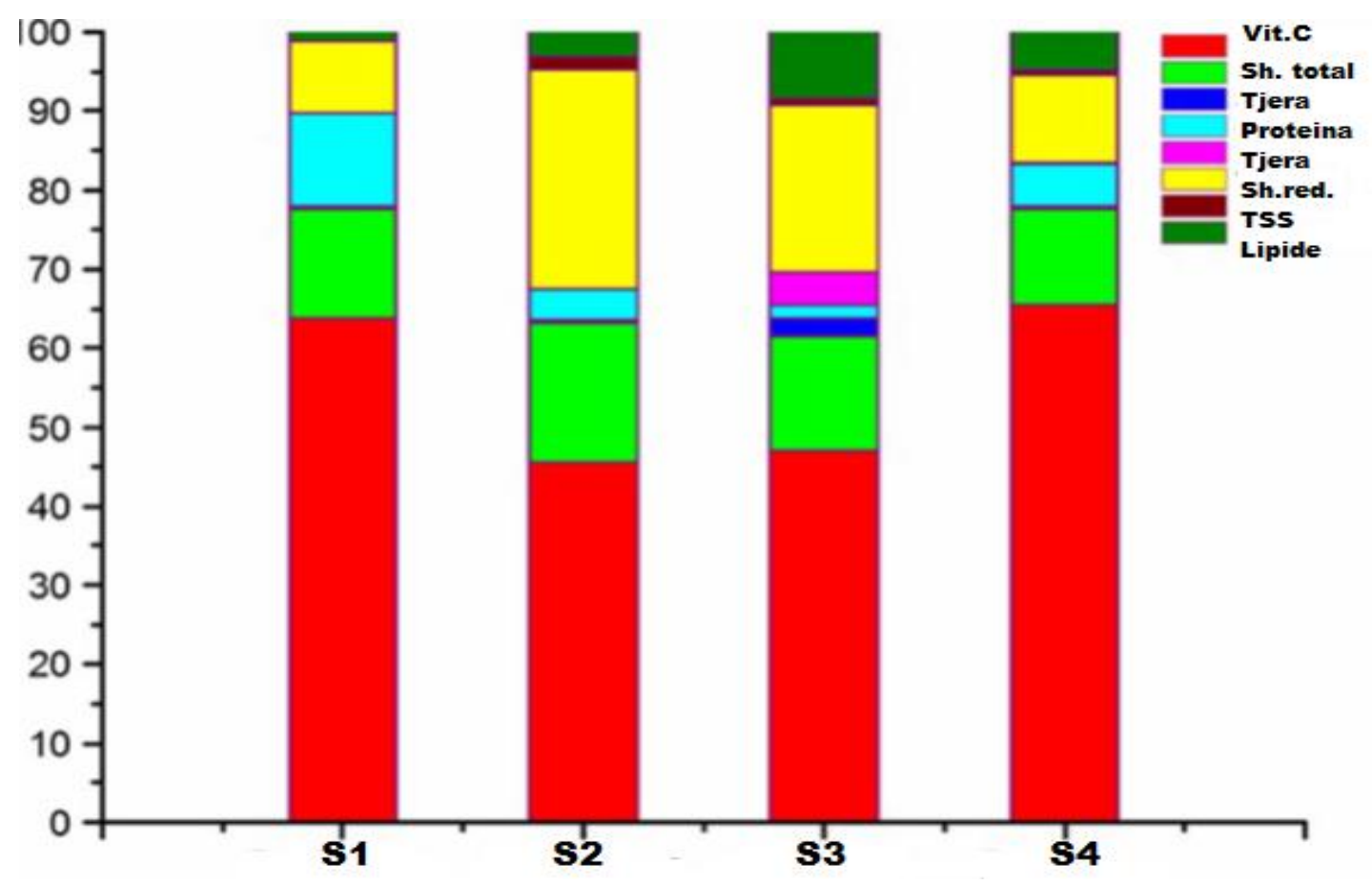

Figura 7. Paraqitja grafike e të dhënave nga parametrat kimik dhe nutricional të dredhëzave të freskëta 


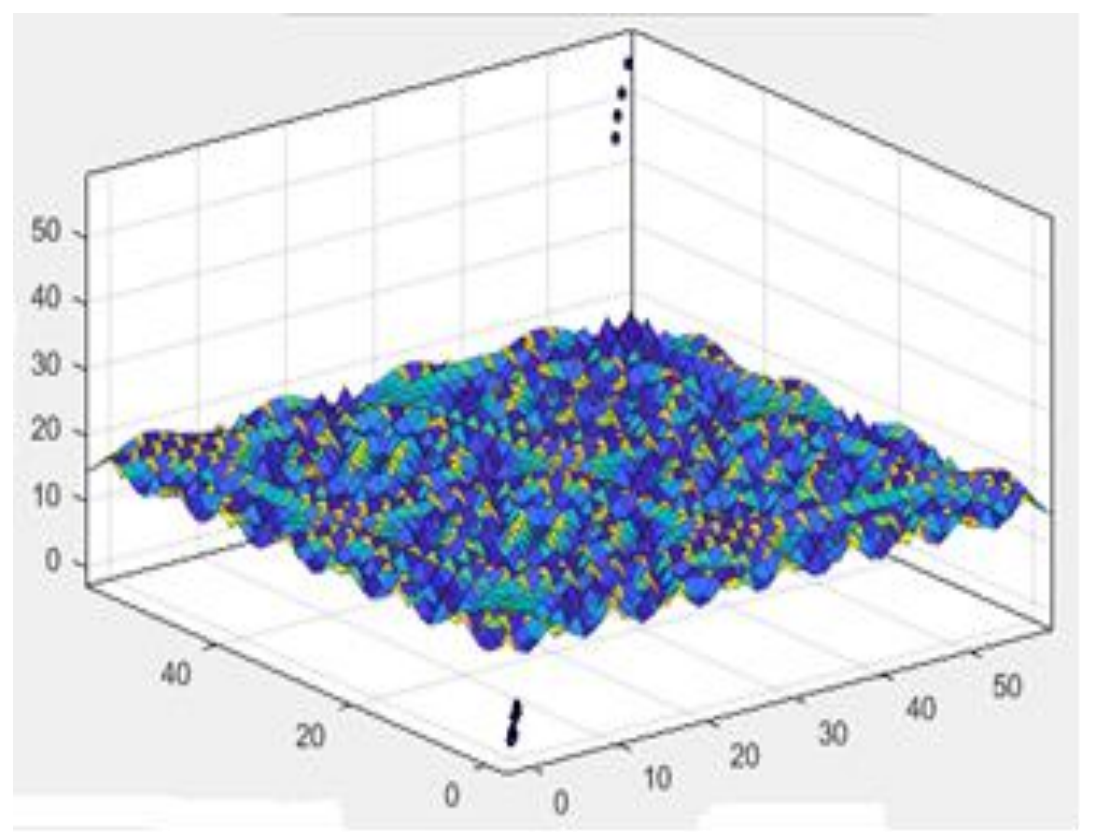

Figura 8. Vizualizimi 3D i të dhënave nga parametrat kimik dhe nutricional të dredhëzave të freskëta

Vlerat e pH priten të janë më të ulëta, që shtrihen nga $3.80 \pm 0.2$ deri $4.30 \pm 0.1$, ku mostra e $\mathrm{S}_{4}$ ka vlerë më të lartë të $\mathrm{pH}$ duke rezultuar me $4.30 \pm 0.1$, këto vlera janë të përafërta me studimet e autorëve tjerë në lidhje me këtë studim (Paz et al.,2013). Vlerat e materies së thatë tek mostrat e dredhëzës shtrihen nga $1.47 \% \pm 0.1$ deri $3.04 \% \pm$ 0.1.Materia e thatë e tretshme e shprehur në shkallën Brix ( ${ }^{\circ}$ Brix), përmbajtja e së cilës shtrihet nga $5.00 \pm 0,1 \circ$ Brix deri $9.00 \pm 0.1 \circ$ Brix , ku si rrjedhojë e këtyre rezultateve mostrat tregojnë se ekziston një sasi mjaft e mirë dhe e lartë e materies së thatë krahasuar me literaturën e referencuar (Paz et al.2013). Mostrat e frutave të freskëta përmbajnë rreth $0.72 \pm 0.2$ deri $0.95 \% \pm 0.1$ të acidit citrik. Aciditeti total i mostrave ka rezultuar të jetë me sasi të ulëta, ku ka ndikuar në uljen e përmbajtjes së materies së thatë. Lidhja mes këtyre dy parametrave , aciditietit dhe materies së thatë është shumë e rëndësishme sepse determinon cilësinë e frutit. Nga shumë studime të bëra nga kultivarë të ndryshëm të dredhëzave, raporti mes aciditetit total dhe materies së thatë ka rezultuar me rëndësi të madhe për shkak se ndikon në ekuilibrin mes sheqernave dhe acideve të frutit. 
Dredhëzat janë burim shumë i mirë i Vitaminës C. Përmbajtja e Vitaminës C ka rezultuar e ndryshme në katër mostrat e studiuara. Mostrat me përmbajtja më të lartë të vitaminës $C$ ishin mostrat $S_{1}$ dhe $S_{2}$ me përmbajtje $50.57 \pm 0.1 \mathrm{mg}$ deri 56.70 $\pm 0.1 \mathrm{mg} / 100 \mathrm{~g}$. Kur krahasojmë këto rezultate me të dhënat e autorëve të tjerë në shumicën e rasteve rezultojnë mostrat që të jenë të cilësisë mesatare sipas referencave të autorit (Giamperi et al.,2012). Dredhëzat e studiuara rezultojnë me përmbajtje të lartë të vitaminës C. Përmbajtja e sheqernave totale shtrihet nga $2.04 \pm 0.1 \mathrm{~g}$ deri në $2.82 \pm$ $0.2 \mathrm{~g} / 100 \mathrm{~g}$. Përmbajtja e sheqernave ka rezultuar e ulët por, duke u bazuar në literaturë shohim se dredhëzat nuk janë burim i mirë i sheqernave sidoqoftë (Hossain et al.,2016;Giamperi et al.,2012). Përmbajtja e proteinave shtrihet nga 0.69土0.1g deri $0.84 \pm 0.2 \mathrm{~g}$ për $100 \mathrm{~g}$ të frutit të dredhëzës , që përshtatet me rezultatet e të dhënave në referencën e autorëve (Hossain et al.,2016;Giamperi et al.,2012). Përmbajtja e lipideve apo yndyrnave është prej $0.22 \pm 0.2 \mathrm{~g}$ deri $0.28 \pm 0.2 \mathrm{~g} / 100 \mathrm{~g}$. Përmbajtja e lipideve ka qenë mjaft e ulët duke u bazuar në referencat e autorëve (Hossain et al.,2016;Giamperi et al.,2012).

Sipas profilit të tij ushqyes (Tabela 2), dredhëzat përfaqësojnë një zgjedhje të shëndetshme ushqimore. Një interes i madh është zhvilluar tek dredhëzat për shkak të përmbajtjes së tyre jashtëzakonisht e lartë e vitaminës $C$ (Tabela 2), që i bën ata një burim i rëndësishëm i kësaj vitamine për ushqimin e njeriut. Së bashku me vitaminën C, folatet luan një rol vendimtar në theksimin e përmbajtjes mikronutriente të dredhëzave kur konsiderojmë se në fruta, është një nga burimet më të pasura natyrore të këtij mikronutrienti thelbësor.

Rezultatet e fituara mund të jenë të dobishme për qartësimin e cilësisë së frutave të dredhëzës dhe përdorimin e tyre si shtesa ushqimore si dhe si ushqime funksionale.

Kështu, mbi bazën e rezultateve të fituara eksperimentale dhe diskutimit të tyre në këtë punim diplome, dredhëzat mund të cilësohen si një "ushqim funksional",sigurimi i përfitimeve shëndetësore përtej ushqyerjes themelore. Si një nga frutat më të njohura të prodhuara dhe të konsumuara në Kosovë, dredhëzat përmbajnë edhe sasitë e 
fitokimikateve (polifenoleve dhe acidit ellagik) dhe mikronutrientë (vitamina dhe karotenoide) të nevojshme për plotsimin e nevojave ditore të organizmit të njeriut.

Dredhëzat të freskëta dhe të ngrira, janë të disponueshme gjatë gjithë vitit, janë poashtu burime dietike të polifenoleve dhe vitaminave, të cilat kontribuojnë në efektet e tyre të vërejtura në shëndet.

Studimet e ndryshme që përfshijnë modele qelizore dhe shtazore japin prova për efektet antikarcinogjene dhe antiproliferative të dredhëzave, kryesisht përmes ë aktivitetit NFkB dhe kundër inflamacionin; sipas hulumtimeve të ndryshme tregohet se elagitannina që gjendet në dredhëza dhe treguar se ushtron efekte të rëndësishme kimoterapeutike.

Hulumtimet epidemiologjike dhe klinike forcojnë më tej dëshmitë mbi përfitimet shëndetësore të dredhëzave. Të dhënat ekzistuese kryesisht nga studimet njerëzore nxjerrin në pah antioksiduesin, anti-inflamatorin dhe antihipertensivën si efekte të dredhëzave, dhe dobësimi i dietës me yndyrë të lartë që shkakton lipemia postprandiale ose stresi oksidativ me ndërhyrje të dredhëzave.

Hulumtimet në zhvillim tregojnë gjithashtu potencialin e dredhëzave në ndryshimin e çrregullimeve neurodegjenerative të lidhura me moshën, gjë që duhet hulumtim i mëtutjeshëm. Roli i dredhëzës si një ushqim funksional mbështetet nga disa hulumtime dhe duhen hulumtime të mëtutjeshme mbi rezultatet e saj shëndetësore parandaluese dhe terapeutike.

Dredhëzat përmbajnë shumë komponentë të rëndësishëm dietikë përfshirë vitamina, minerale, folate dhe fibra, dhe janë të pasura burim i komponimeve fitokimike të përfaqësuara kryesisht nga polifenolet. Edhe pse komponimet fenolike në dredhëza njihen më së miri për veprimet e tyre antioksiduese dhe anti-inflamatore, së fundmi hulumtimet kanë treguar se bioaktivitetet e tyre shtrihen në shumë drejtime të tjera gjithashtu. 


\section{KONKLUZIONET}

Dredhëzat janë një nga frutat e vogla më të njohura të konsumuara në të gjithë botën, pasi ato janë të disponueshme gjatë gjithë vitit si produkt i freskët ose i ngrirë, përfaqësojnë një burim dietik përkatës të vitaminave, mineraleve dhe fitokimikanëve, të cilat kontribuojnë në efektet e saj shëndetësore.

Ky studim informon që dredhëzat e kopshtit (Fragaria $x$ Ananasa Duch.) të kultivuara dhe të rritura në Kosovë rezultojnë me sasi të konsiderueshme të Vitaminës C, sheqerna dhe minerale.Vlerat e tyre ushqyese (nutricionale) i bën të përshtatshëme për konsum. Sipas studimit tonë dredhëzat kanë përmbajtje të lartë të Vitaminës C, sasi mesatare të sheqernave dhe nivel të ulët të lipideve dhe proteinave, që rezultojnë sipas konditave normale. Sipas rezultave këto dredhëza janë të përshtatshme për konsum dhe janë burim i mirë i vitaminës $\mathrm{C}$ dhe nutritientëve tjerë.Si studies dhe njohës së mënyrës të të ushqyerit dhe inkurajimit të tij, vlen të ceket se dredhëzat janë fruta me vlerë nutricionale të lartë, kalori të ulëta, përmbajtje të lartë të ujit dhe si të tilla inkurajojmë që të konsumohen gjatë dietës ushqimore. 


\section{REFERENCAT}

[1] Aaby K., Wrolstad E.R., Ekeberg D., Skrede G. (2007).Polyphenol Composition and Antioxidant Activity in Strawberry Purees; Impact of Achene Level and Storage. J. Agric. Food Chem. 55, 5156-5166

[2] AOAC (2016).Official method of analysis. Maryland, USA: Publication by AOAC.

[3] Bakkalbasi E., Mentes O., Artik, N. (2009). Food ellagitannins-occurrence, effects of processing and storage. Crit. Rev. Food Sci. Nutr. 49:283-298.

[4]Giampieri,F.Tulipani $\quad$ S.,Suarez $\quad$ A.M.,Quiles $\quad$ L.J.,Mezzetti B.,BattinoM.(2012).The strawberry:Composition, nutritional quality, and impact on human health. Nutrition 28, 9-19.

[5] Hossain A.,Begum P.,Zannat S.M.,Rahman H.,Ahsan A.,Islam N.Sh.(2016). Nutrient composition of strawberry genotypes cultivated in a horticulture farm. Food Chemistry 199,648-652.

[6] Liu L.,Ji L.M. Chen M., Sun M.,Fu X.,Li L., Gao Sh.D.,Zhu Y.C. (2016). The flavor and nutritional characteristic of four strawberry varieties cultured in soilless system.Food Science \& Nutrition 4(6), 858-868.

[7] Nielsen S.S.(2009). Phenol-Sulfuric Acid Method for Total Carbohydrates.Food Analysis Laboratory Manual 47-53.

[8] Marinova D.,Ribarova F.(2007). HPLC determination of carotenoids in Bulgarian berries. Journal of Food Composition and Analysis 20,370-374.

[9] Pavlovska G.,Dukovska,E.,Knights,A.V.,Jankuloska,V.(2014).Influence of temperature and time of storage on amount of vitamin $\mathrm{C}$ in strawberries.Journal of Hygienic Engineering and Design 11,15-19.

[10] Paz J., Yahia M.E.,Bustamante R.N.,Martinez P.D.J.,Minakata E.P.M.,Junquera I.V.,Muniz A.C., Prieto G.V., Reyes O.E.(2013). Physical attributes and chemical composition of organic strawberry fruit (Fragaria x Ananassa Duch, Cv. Albion) at six stages of ripening. Food Chemistry 138,372-381. 
[11] Perez M.E., Camacaro GJ., Hadley P., Battey N. H, Carew J. G.(2002).Pattern of growth and development of strawberry cultivars Elsanta, Bolero and Everest J Amer Soc Hort Sci, 127(6): 901-907.

[12] Scalbert A., Johnson T.I.,Saltmarsh M.(2005). Polyphenols: antioxidants and beyond. Am J Clin Nutr 81(suppl),215S-7S.

[13] Skrovankova S.,Sumczynski D.,Mlcek J.,Jurikova T.,Sochor J.(2015). Bioactive Compounds and Antioxidant Activity in Different Types of Berries. Int. J. Mol. Sci.16, 24673-24706.

[14] Wolfe K.L.,He X., Zhang Q.,Kang X.,Dong M.,Liu R.(2008). Cellular Antioxidant Activity of Common Fruits.Journal of Agricultural and Food Chemistry.56(18):8418-26. 